\title{
The Supanberget area - basement imbrication and detached foreland thrusting in the Tertiary fold-and-thrust belt, Svalbard
}

\author{
WINFRIED K. DALLMANN AND HARMON D. MAHER, JR.
}

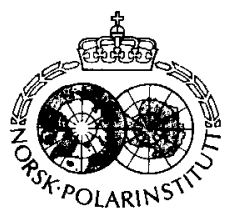

\begin{abstract}
Dallmann, W.K. \& Maher, H.D., Jr. 1989: The Supanberget area - basement imbrication and detached foreland thrusting in the Tertiary fold-and thrust belt, Svalbard. Polar Research 7, 95-107.

The Supanberget area, situated in the southern part of the Tertiary Spitsbergen fold-and-thrust belt, occupies a position mainly within the central zone of the belt, characterized by basement-involved thrusting, but includes part of an eastern foreland zone of detached, thin-skinned thrust tectonics. The peculiar feature of Supanberget is the thrust- 'sliced' tectonic style that deforms a previously tightly folded basementcover contact. Foreland structures indicate the additional presence of a subsurface detachment at a deeper structural level. Contrasts in magnitude and orientation of basement anisotropies may control lateral changes in tectonic style.
\end{abstract}

Winfried K. Dallmann, Norsk Polarinstitutt, P.O. Box 158, N-1330 Oslo Lufthavn, Norway; Harmon D. Maher, Jr., Dept. of Geography and Geology, University of Nebraska, Omaha, Nebraska 68182, U.S.A.; March 1989 (revised August 1989).

The Tertiary fold-and-thrust belt of Spitsbergen, Svalbard, is situated in an overall dextral transpressive, intracratonic plate regime. Models proposed and established by Harland (1969), Lowell (1972), Birkenmajer (1972), Harland \& Horsfield (1974), and Kellogg (1975) have been further constrained by evidence from the seafloor off the Barents Shelf (Myhre et al. 1982; Spencer et al. 1984; Eldholm et al. 1987; Vågnes et al. 1988).

Recent research in the fold-and-thrust belt provides a revised and expanded understanding of its structure. In spite of the overall transpressive regime, detailed investigations in the belt indicate that almost solely convergent motions are responsible for the observed structures (Andresen et al. 1988a, b; Bergh et al. 1988; Dallmann 1988a, b; Maher 1988a, b; Nøttvedt et al. 1988a, b). The eastward extension of the deformed foreland significantly exceeds what previously was believed (Andresen et al. 1988a, b; Haremo et al. 1988; Haremo \& Andresen 1988). These results led to the idea of decoupled transform and compressive movements, the transform component being restricted to western offshore areas (Steel et al. 1985; Maher \& Craddock 1988; Nøttvedt et al. $1988 \mathrm{a}, \mathrm{b})$. A distinct zonation parallel to the trend of the belt has been worked out (Maher 1988a, b; Dallmann \& Maher 1988), dividing it into a western zone of uplift of the Caledonian basement with an uncertain, but varying amount of Tertiary deformation, a central zone of mainly thickskinned, basement-involved thrusts, and an eastern foreland zone of detached, thin-skinned thrust systems with décollement and ramp-flat geometries.

Lateral changes of tectonic style within these zones are common, and can partly be ascribed to the different structural depths exposed (Dallmann 1988b; Maher 1988a; Dallmann \& Maher 1988). The basement-involved thrust zones vary from simpler areas with large-scale folds cut by individual thrusts to complexly imbricated and tightly folded sections. The latter have been described from several places in Oscar II Land (St. Jonsfjorden-Winsnes \& Ohta 1988). South of Isfjorden, similar structures have - as far as we know - only been observed in the Supanberget area (Fig. 1). The lack of more frequent observations may be due to the extensive ice cover along the basementcover contact in Wedel Jarlsberg Land.

In this article, we describe the structure of the Supanberget area, discuss its geometry and origin, and consider a connection between the structural style of the thrust zone and the basement anisotropies. 


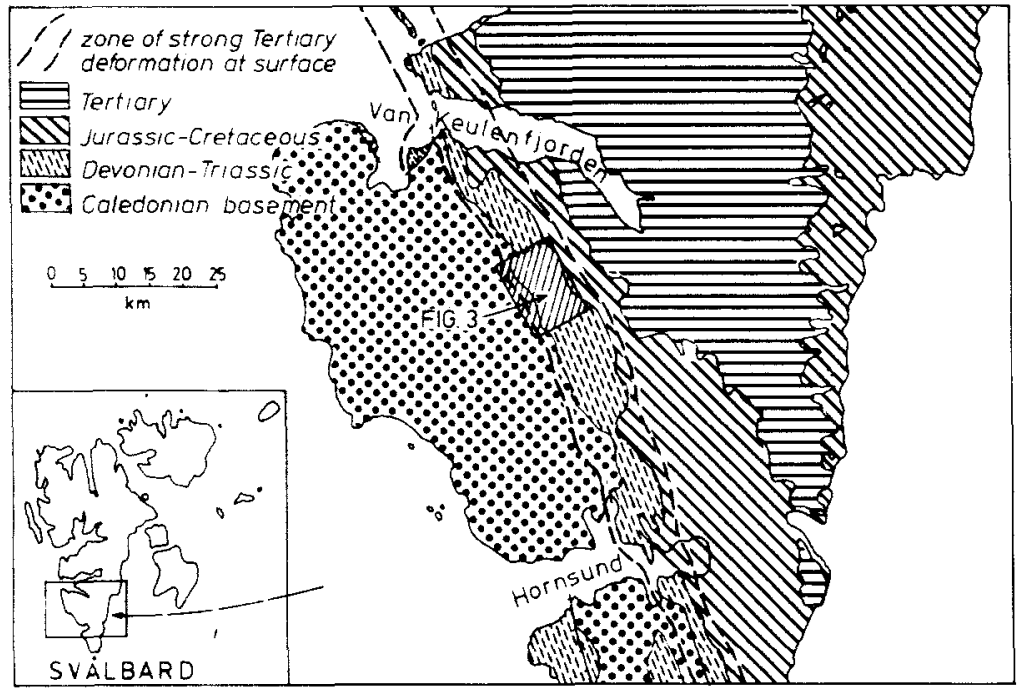

Fig. 1. Location of the Supanberget area and its position within the zone of strong Tertiary deformation in S Spitsbergen.

\section{Description of the Supanberget area}

\section{Location, accessibility and exposure}

Supanberget is situated in the interior of Wedel Jarlsberg Land, $20 \mathrm{~km} \mathrm{~S}$ of Van Keulenfjorden, and is part of the central NW-SE trending ridge separating the Caledonian basement in the SW from the post-Caledonian cover strata in the NE (Fig. 1). The area is extensively glaciated. The easiest access by foot is from Van Keulenfjorden along the glacier 'Penckbreen'. Exposures along the mountain sides and ridge crests are mostly excellent, and only a few small areas are covered with moraines or scree. The majority of the ridges can easily be set foot on from the glaciers, but only a minor part of them can be fully surveyed without mountaineering or helicopter support.

\section{Stratigraphy and lithology}

Caledonian basement strata. - The Caledonian basement of the study area is assigned to the Magnethøgda sequence ('Magnethøgda Group' of Harland (1978)) of Precambrian, possibly Middle Proterozoic age (Flood et al. 1971; Y. Ohta pers. comm. 1988). No detailed descriptions of the lithologies at Supanberget have been published, but similar rocks from the same stratigraphic sequence have been described by Hauser (1982 - 'Antoniabreen Succession'). These strata lie below a major angular unconformity within the basement rocks, and are part of the 'older sequence' of Bjornerud (1987). In the investigated area, the lithologies can be subdivided into two units. One consists of carbonate rocks, mainly massive grey to yellowish dolomites, with subordinate banded marbles. The other unit consists of dark grey phyllites interlayered with massive quartzite layers up to several meters in thickness. A low angle discordance exists between the lithologic banding of this metaclastic succession and the contact with the carbonate succession. The stratigraphic relationship between the individual units has not been investigated.

Post-Caledonian cover strata. - Middle Carboniferous through Lower Jurassic strata of the Supanberget area lie within the larger area in which Różycki (1959) describes the post-Caledonian stratigraphy. However, Cutbill \& Challinor (1965) revised the Carboniferous and Permian stratigraphy, and age relations were again reconsidered by Steel \& Worsley (1984). Upper Carboniferous through Permian sections have also been described by Nysæther (1977) from Polakkfjellet, $18 \mathrm{~km}$ SE of Supanberget. The stratigraphic column, Fig. 2, is based on these descriptions, but modified by our own observations.

The Carboniferous and Permian stratigraphy is complexly deformed and partly cut by thrusts at Supanberget. In order to decipher the stratigraphy, it is therefore important to observe the undisturbed Zittelberget section to the north. In 


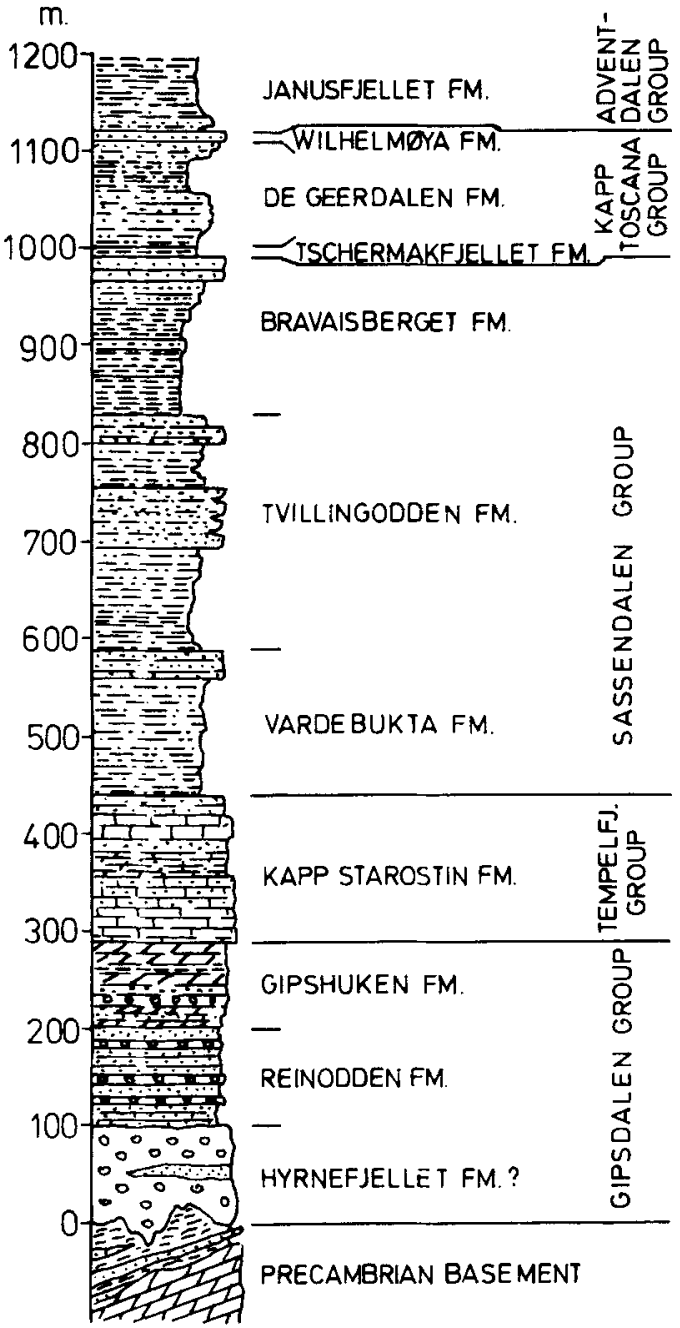

Fig. 2. Stratigraphic column of the post-Caledonian sequence of the Supanberget area. Thicknesses are approximate.

addition, a complicating factor is that the Lower Permian strata (Gipshuken Formation) undergo fairly rapid lateral facies changes towards more clastic dominated deposits to the south.

The lowermost unit is a red, polymict conglomerate succession with intercalated, discontinuous red sandstones of probably Middle (or Upper?) Carboniferous age, and it represents a facies equivalent of the Hyrnefjellet Formation (Birkenmajer 1964) at Hornsund. The rocks vary in thickness from 0 to c. $150 \mathrm{~m}$, and appear to be deposited in Carboniferous graben and halfgraben structures (Figs. 3, 4- section D, and 7).

The overlying, yellow to grey sandstone and conglomerate succession $(\mathrm{c} .100 \mathrm{~m})$ can be traced continuously into the Reinodden Formation at Van Keulenfjorden. It also seems to be an equivalent of the Drevbreen beds at Polakkfjellet (Nysæther 1977) and of the Treskelodden Formation at Hornsund (Birkenmajer 1964). Steel \& Worsley (1984) assume that these three Upper Carboniferous to lowermost Permian successions are correlatable. The formation is thinly layered, interbedded with minor dolomites and limestones, and numerous shaly layers as well as clast-supported conglomerate beds with rounded clasts and a porous matrix. These parameters are consistent with a relatively incompetent behaviour.

The overlying Lower Permian Gipshuken Formation (c. $80-100 \mathrm{~m}$ ) consists mainly of light grey to yellowish weathering dolomitic limestones and dolomites with intercalated cross-bedded sandstones, polymict conglomerates, and shales. The facies of the lower part becomes richer in conglomerates to the south, where the boundary towards the underlying Reinodden Formation is not well defined.

The Upper Permian Kapp Starostin Formation (c. $150 \mathrm{~m}$ ) is dominated by fossiliferous, partly siliceous limestones. Cherts that are typical for this formation further north are here mostly substituted by shales, silt- and sandstones which occur preferentially in the upper part. The Kapp Starostin Formation still forms the most competent unit of the post-Caledonian succession in this area.

The Lower and Middle Triassic formations of the Sassendalen Group consist of sandstone/ shale alternations, representing four main coarsening upward cycles which total approximately $550 \mathrm{~m}$ thickness. The upper unit of the group, the Bravaisberget Formation, contains c. $120 \mathrm{~m}$ of incompetent, bituminous shales and a c. $40 \mathrm{~m}$ thick capping sandstone. The overlying Upper Triassic to Lower Jurassic Kapp Toscana Group is made up of c. $120 \mathrm{~m}$ marginal marine sand- and siltstones (Mørk et al. 1982). Clastic sedimentation continues into the Jurassic/Lower Cretaceous Janusfjellet Formation, consisting of highly bituminous siltstones and shales.

\section{Structure of the Supanberget thrust system}

The basement-involved zone. - The western, basement-involved zone of the fold-and-thrust 




Fig. 3. Geological and structural map of the Supanberget area. Discussion in the text. 
belt is exposed in the central ridge, within the mountains Nupen, Zittelberget, Supanberget, Helhornet, Staszicfjellet, Flinthornet, and Stanislawskikammen (Fig. 3). Its lowermost exposed thrust overlies overturned Triassic and Upper Permian strata, and can be traced along the west side of Stanislawskikammen to Supanberget (Figs. 3, 5, 6, and 7), but does not reappear in the mountains to the north. The regional relationship suggests, however, that the incipient thrust ramp at Engadinerberget (Fig. 8) may be related to this thrust system, as indicated in Fig. 4 (section A). Also, the continuity of the structures between Engadinerberget and Richthofenberget argues against the interpretation that the thrust could turn NE and continue beneath the glacier (Penckbreen). Although the map (Fig. 3) would leave room to draw the regional folds with a thrust offset below Penckbreen, the straight-forward continuation of their axial traces does at least not permit a significant offset (compare Figs. 3 and
10). In any case, the thrust offset decreases significantly in the Passhatten-Engadinerberget area (Fig. 3).

On either side of the thrust, sandstones and dolomites are strongly tectonized over a thickness of tens of meters. The overlying carbonate rocks of the lower part of the Gipshuken Formation are overturned and upward bounded by another, obliquely cutting thrust fault at the NE end of Supanberget (Fig. 5). To the south, this fault cuts up the mountain side, but down section into the Reinodden Formation due to an oblique crosssection view from structures more to the east in the northern portions to structures more to the west in the southern portions. A higher thrust splay separates a lower, overturned from an upper, upright slice, each consisting of the Reinodden and basal Gipshuken Formations (Figs. 3, 4 - section B, 5, and 6).

Reinodden strata above these thrusts are locally overturned again. These overturned beds re-
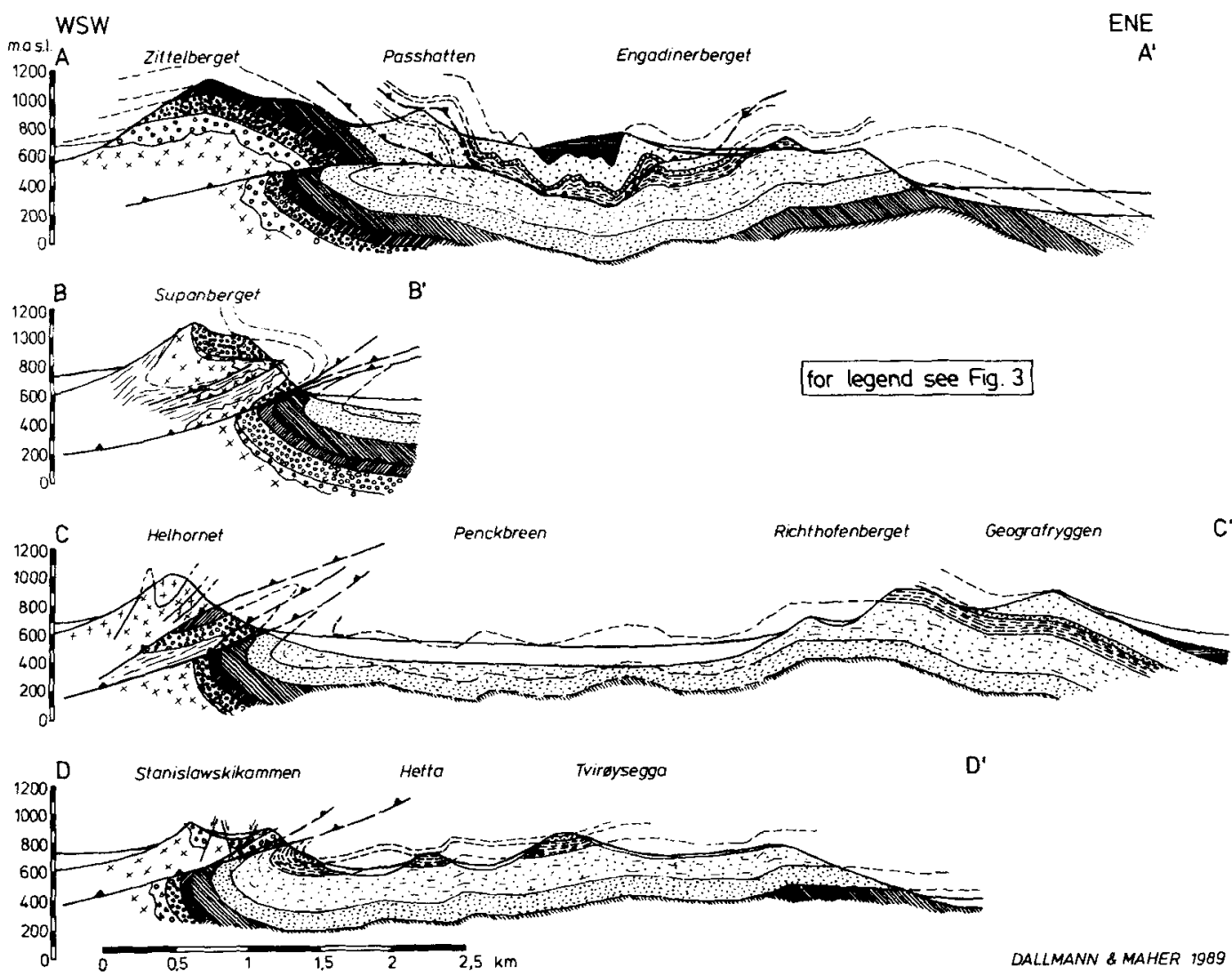

Fig. 4. Geological cross sections through the Supanberget area. Positions indicated in Fig. 3. Discussion in the text. 

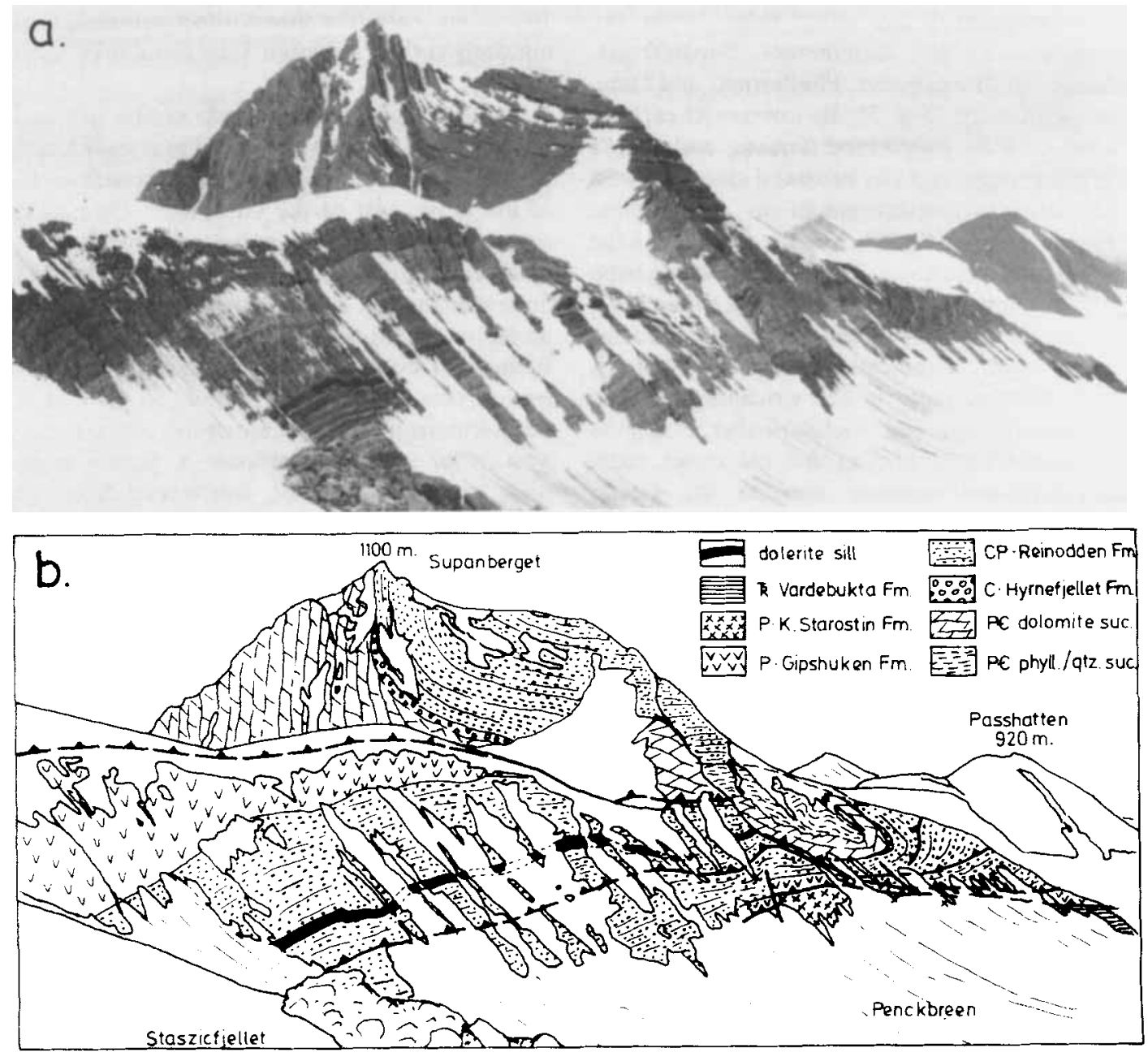

Fig. 5. Oblique view (a) and gcological interpretation (b) of Supanberget, seen from the basal thrust in front of Staszicfjellet towards NNW, showing the basement-cored, tight fold with the lower limb dissccted by thrust faults.

present the lower limb of a recumbent fold with a NW-SE trending subhorizontal axis. The core of this fold is made up of basement rocks including both the dolomite and the phyllite/quartzite units, which are deformed by internal thrusts (Figs. 3, 4 - section $B, 5$, and 6 ). The basement/cover contact is irregular and depositional, with local paleokarst depressions filled with red conglomerates at the base of the Carboniferous strata. The upper limb of the recumbent fold bends into a vertical position in the upper region of Supanberget (Figs. 4 - section $\mathrm{B}$, and 5 ).

To the north, at Zittelberget, the Carboniferous/Permian strata form a northeastward dipping monocline (Fig. 4) which is thought to be the continuation of the fold structure on Supanberget. The basement rocks in these folded, but at macro-scale - unfaulted parts of the structure belong solely to the dolomite succession.

South of Supanberget, exposures are less continuous. From Helhornet to Stanislawskikammen, only basement rocks along with halfgraben structures, filled with Carboniferous red conglomerates, overlie the basal thrust. The discontinuous distribution of Carboniferous red beds and their coarse clastic character in the study area lead us to assume a Carboniferous age of the graben structures. The basement rocks, however, contain one to two more steeply dipping thrust faults, indicating that the imbrication structures 


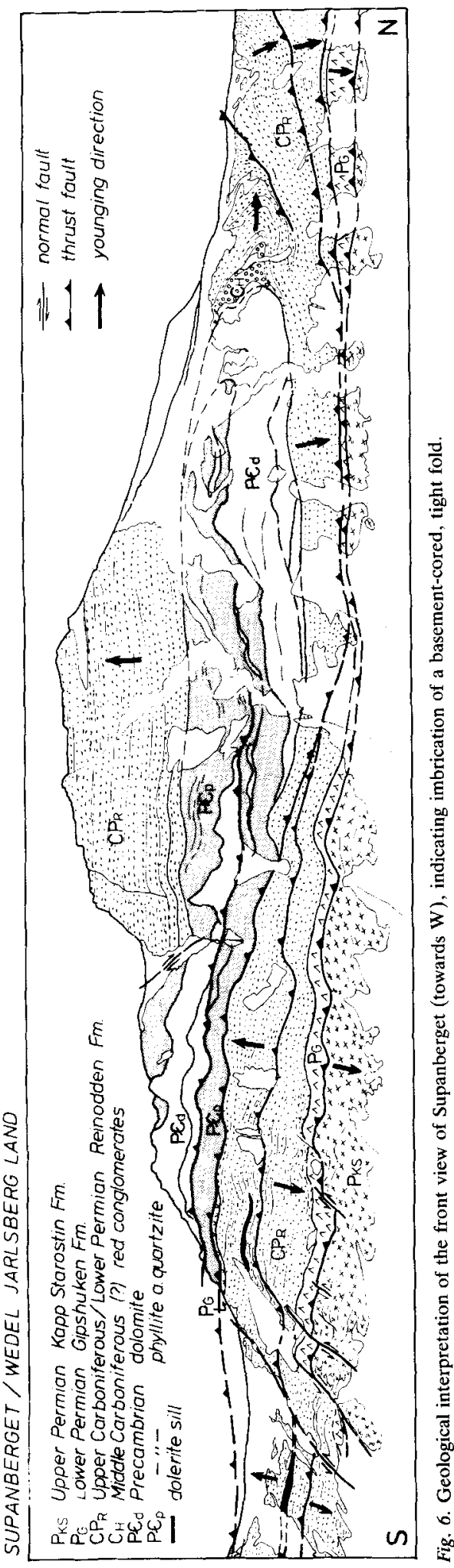

of the Supanberget thrust system are continuous to the south (Figs. 3 and 4 - sections $C$ and D). Also, the unconformable contact between the basement rocks and red conglomerates is overturned, suggesting a continuation of the highest overturned fold structure on Supanberget.

The foreland zone. - Two ridges surrounded by glaciers extend from the central ridge northeastward into the foreland zone, where mainly Triassic strata are exposed. The northern ridge is composed of Passhatten, Engadinerberget, and Wallisberget, the southern one of Hetta, Tvirøysegga, Richthofenberget, and Geografryggen. Major fold structures are continuous from one ridge to the other, indicating that no macroscopic thrust fault is hidden beneath the glaciers in between (Fig. 3).

The overturned Triassic strata underlying the basal thrust of the central ridge can be observed to turn back into right-way-up horizontal orientation between Stanislawskikammen and Hetta (Fig. 4section D). To the NE along the ridges of Hetta and Tvirøysegga, strata are folded with a subhorizontal enveloping surface. Folds tend to be monoclinal steps, facing both the NE and $\mathrm{SW}$. At the northeastern tip of Tvirøysegga, the Upper Permian Kapp Starostin Formation just appears in the core of a gently NW dipping antiform (Figs. 3 and 4 - section D).

Similar structures continue through Richthofenberget. The major feature here is a monocline with a SW-down displacement of $200 \mathrm{~m}$ in the Triassic strata. To the NE, at Geografryggen, the bedding planes form two further monoclines, the easternmost limb of which represents the western flank of the Tertiary central basin of Spitsbergen (Figs. 3 and $4-$ section C).

At Passhatten, the basement-involved thrust is absent and none of the outcropping strata are overturned. Within the Triassic strata of the monoclinal structure of Zittelberget and Passhatten, however, there are décollement-type folds with minor faults. To the east is a tight synclinorium at Engadinerpasset (Fig. 4-section A). From here to the NE, structures are continuous with the southern ridge. On the major SW dipping monocline at Engadinerberget, a smaller-scale NE directed complex thrust ramp is exposed (Fig. 8) (Rożycki 1959). The structural high between this monocline and the NE dipping monoclinal flank of the central basin at Wallisberget is composed of box folds (Fig. 4 - section A). 


\section{Discussion}

\section{Thrust geometry}

The basement-involved part of the described structure is an imbricate fan developed within the core of a tight fold. The thrust system is blind or almost blind to the north and east, whereas its southern continuation is not known due to the extensive glacial cover (it may continue all the way to Hornsund, c. $35 \mathrm{~km}$ ). The basal thrust, at which basement rocks are thrust over Paleozoic and Triassic strata, is continuous across the study area, whereas the imbricate splays cannot be traced laterally (Fig. 3). Along the southern half of the Supanberget eastern face, the middie one of the three exposed thrusts probably forms a splay between the two others, with the upper branch line exposed (middle part of Fig. 6). Alternatively, the thrusts at Supanberget may be part of a duplex structure with two horses exposed (terminology after Boyer \& Elliott (1982)).

Structures at Passhatten and the western part of Engadinerberget overlie the Supanberget thrust system (Fig. 4). Here, Triassic and Jurassic strata are folded at a short wavelength, suggesting a décollement zone at a low depth, i.e. within shaly parts of the Sassendalen Group. Elsewhere in the fold belt, comparable structures were recognized above décollement zones (Maher et al. 1986; Dallmann 1988a). The décollement may - as the most simple model - be the subsurface continuation of the Supanberget thrust system. The ramp structure at Engadinerberget (Fig. 8), where minor thrusts ascent from the Bravaisberget Formation shales through the overlying sandstone sequence into the Tschermakfjellet Formation shales, has likely a ramp-flat geometry associated with the décollement. This interpretation (Fig. $4-$ section A) easily explains the observed surface structures. Possible alternative interpretations (that we consider less likely and do not address further) would be that the Supanberget thrust system terminates at a tip line further west, and that the detachment zone beneath PasshattenEngadinerberget is the surface continuation of some deeper rooted structure.

A minimum estimate of shortening within the Zittelberget-Engadinerberget area can be made by measuring the shortening accommodated by the fold structures overlying the thrust, which is about $500-750 \mathrm{~m}$ (sinuous-bed estimate). (This amount must equal the sum of the transport along the thrusts and the shortening by drag folds beneath the thrust.) A possible larger thrust displacement would imply that there have to be further, not observed surface structures in the foreland, e.g. bedding parallel thrusts, or backthrusts in the Passhatten area (compare Fig. 4 - section A). Both types of structure have been observed further north in the fold-and-thrust belt (Dallmann 1988), and their possible existence must also be considered here, because it could greatly increase the amount of shortening related to the thrust system.

Further south, in the area between Supanberget and Stanislawskikammen, it is possible to estimate a minimum amount of shortening by matching stratigraphic units across the thrust. It is greatest at Stanislawskikammen (Fig. 4 - section D), where thrust displacement is at least $1 \mathrm{~km}$. An additional amount is accommodated by drag folding.

Structures at the southern ridges between Hetta and Geografryggen (Figs. 3 and 4 - sections $C$ and D) and their northerly continuation at the eastern part of Engadinerberget and Wallisberget (Figs. 3 and $4-$ section A) are clearly situated at a structural level lower than the Supanberget thrust system. Here, the Triassic strata are folded at $\mathrm{km}$-scale wavelengths. Folds tend to be composed of monoclines, box folds, etc. The geometry is very similar to a fold pattern resulting from subsurface detachments with ramp-flat geometries as discussed by Gretener (1972) and Suppe (1983) (Fig. 9). A possible detachment zone would, however, be situated at a greater depth, as many of the Permian strata are involved in the folding (Fig. 4 - section D). This is clear from mapping in adjacent areas to the south (Różycki 1959; Birkenmajer 1964).

It is, however, not easy to find lithologies beneath the Permian strata suited to accommodate the long flats of such a detached thrust fault. While detachments in the northern part of the fold-and-thrust belt often are developed within gypsum layers of the Gipshuken Formation (Harland \& Horsfield 1974; Maher 1988a), gypsum or anhydrite seems almost to be absent in the present area. The shaly layers in the Carboniferous to Lower Permian succession observed at Zittelberget and Supanberget are quite thin and not continuous. On the other hand, attenuating shaly beds could be the reason for the relatively frequent ramping of the thrust fault as constructed in Fig. 9. 

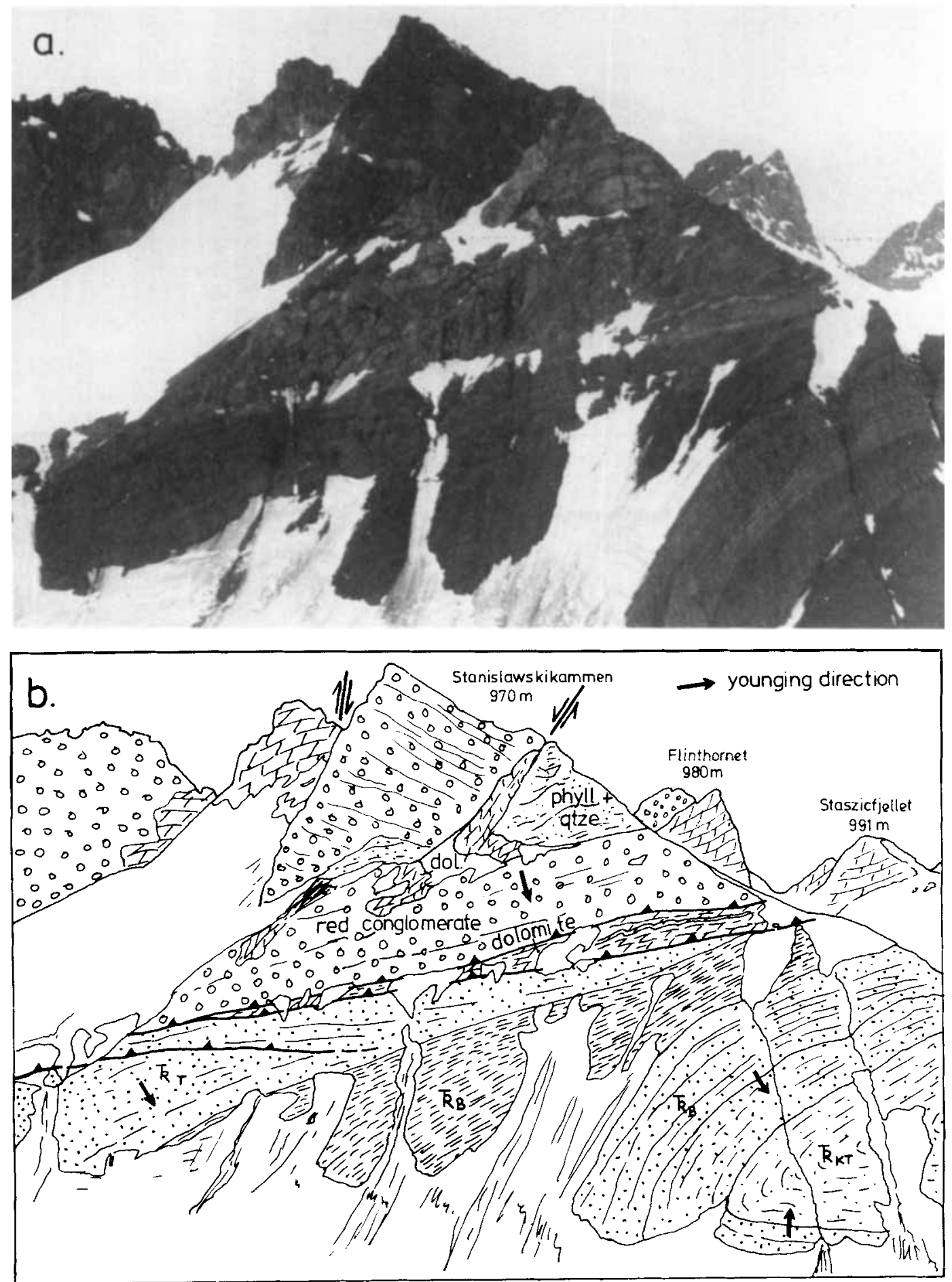

Fig. 7. Side view (a) and geological interpretation (b) of Stanislawskikammen, seen from helicopter towards NW. The structure represents basement-involved imbrication and drag folding below the basal thrust fault. 

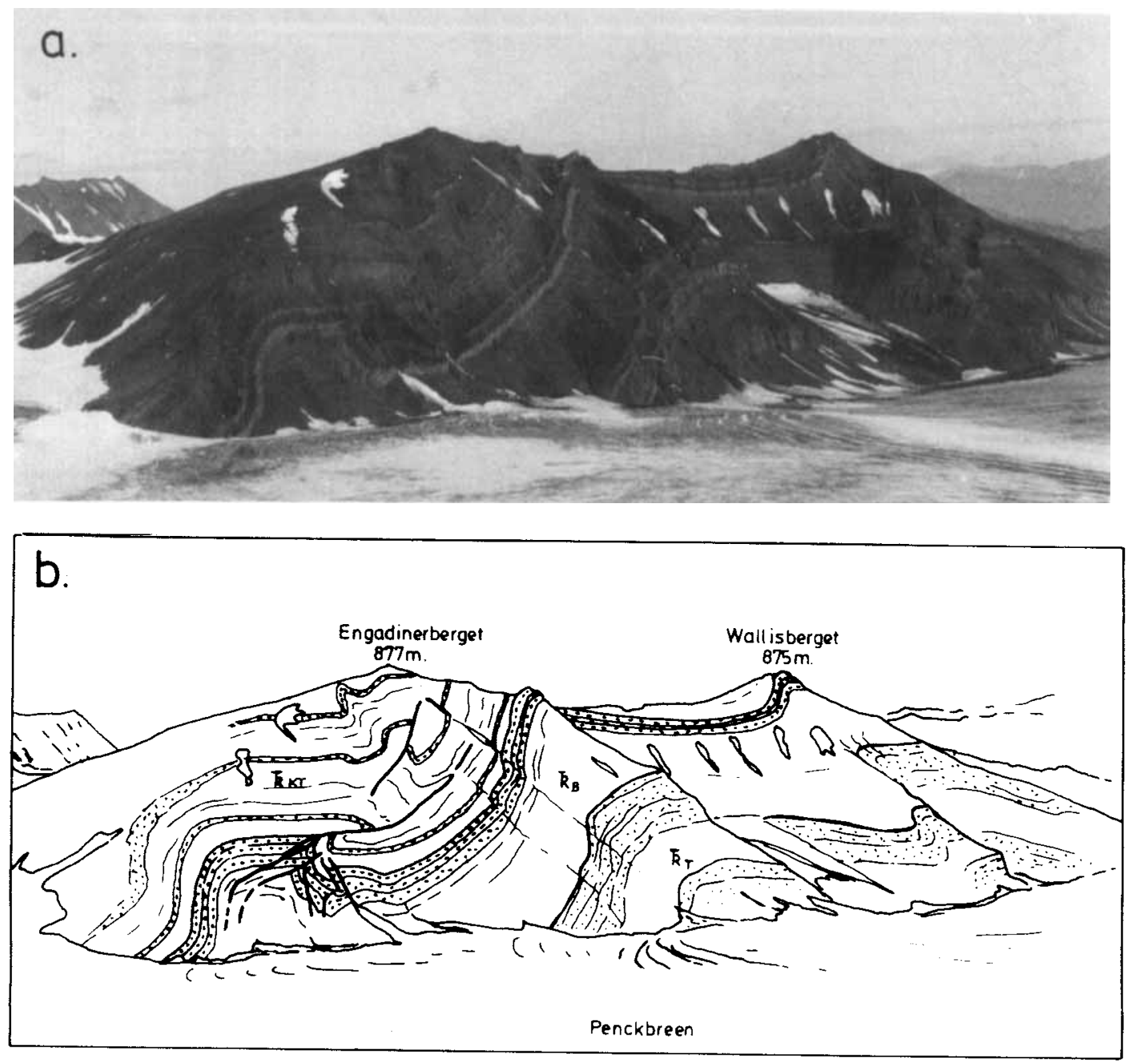

Fig. 8. Oblique view (a) and geological interpretation (b) of Engadinerberget, seen from helicopter towards NNW. The structure represents an incipient thrust system with a ramp-flat geometry, and is probably part of the foreland continuation of the Supanberget thrust system.

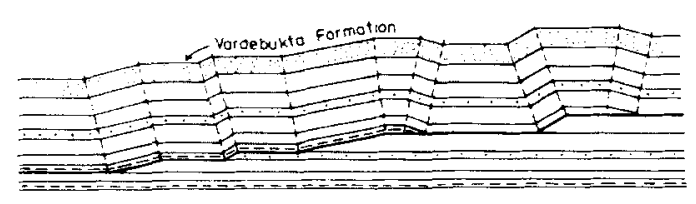

Fig. 9. The structural contour of the Triassic Vardebukta Formation at Hetta and Tvirøysegga (Fig. 4 - section D), explained by an underlying detachment with a ramp-flat geometry. The indicated bedding units are extrapolated from the geometry of the surface fault-bend folds, and are not meant to show the real stratigraphy. which is uncertain because of the lateral inconsistency of the Late Paleozoic strata. The depth of the detachment is schematic.
Other possible candidates for a subsurface detachment are shaly layers of the Lower Carboniferous Billefjorden Group, or even phyllites of the Vendian Gåshamna Formation (basement), both common stratigraphical units in the area north of Hornsund (Birkenmajer 1964, 1978).

The orientation of the shortening direction and the regional fold axis is documented in Fig. 10. The horizontal fold axes oriented parallel to the trend of the $300 \mathrm{~km}$ long fold belt and the thinskinned style are most easily explained by for- 


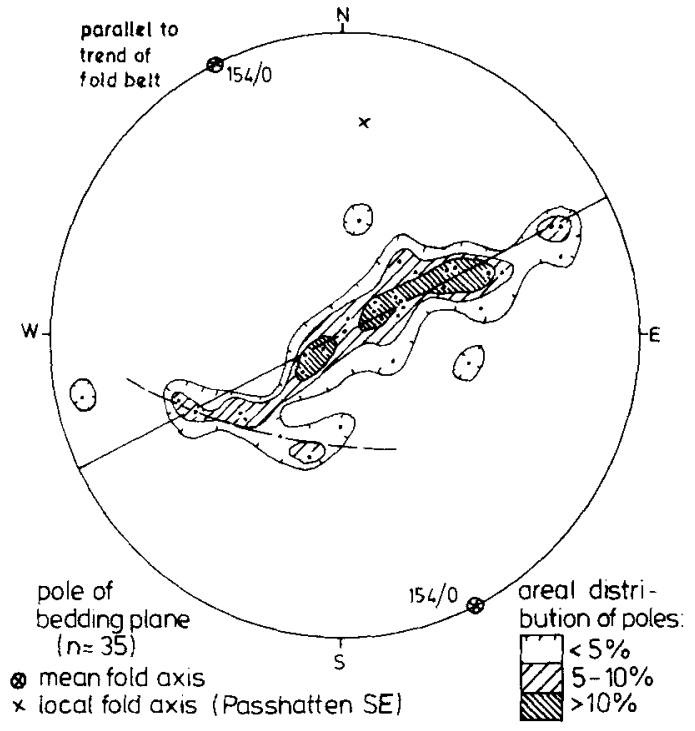

Fig. 10. Stereographic equal area projection of poles to bedding planes in the cover strata of the Supanberget area (Fig. 3), indicating deformation by convergent tectonics. The mean regional fold axis is horizontal and parallel to the trend of the fold belt. The deviating poles in the SW are measured along one local fold at Passhatten (SE ridge), which probably has developed by differential movement along the over- and underlying detachments.

mation in a convergent regime. Evidence for block rotation required by other regimes (e.g. dextral transpression) is lacking in this area.

\section{Nature of basement involvement}

A striking phenomenon is that the lithologic layering in the metamorphic basement apparently is not folded in the same way as in the cover strata. Folds observed in the basement rocks are of different style and orientation, and are therefore supposed to be older, probably of Caledonian age. In one case ( $\mathrm{N}$ face of Supanberget), folds within the basement are clearly truncated by the Caledonian unconformity. Similar relations can be observed elsewhere (e.g. Handley 1983).

We therefore suggest that the basement rocks were dominantly deformed by fracturing, slip along foliation, and faulting during the Tertiary deformation episode.

In the massive dolomites of the basement, the fracture pattern is quite complex, and a statistical analysis has not yet been done. However, there is an obvious relation between the character of anisotropy of the basement rocks and the style of deformation of the adjacent cover rocks. Where massive dolomites underlie the unconformity, the latter are folded gently or form huge, open flexures, and may be dissected by a single, brittle thrust fault (Fig. 4-sections A and B). This style of deformation has also been described from a place further north in Wedel Jarlsberg Land (Berzeliustinden-Dallmann 1988a).

Where the banded phyllite/quartzite sequence underlies the unconformity, their foliation controls the thrust direction (or is rotated into the thrust direction), and folds of the overlying strata are tight and overturned (Fig. 4 - sections B and C). Internal thrust faults within the basement rocks can be observed (Figs. 4 - section B, and 6 ). In areas where the Supanberget imbricate thrust system can be observed to dissect the unconformity down into the basement, phyllites always form part of the basement lithology (Figs. 3 and 4 - section D).

As one would expect, contrast in the degree of basement anisotropy development (phyllite/ quartzite versus dolomite) and a favourable orientation control the deformation style in the immediately overlying cover strata. Areas with strongly developed basement anisotropies (phyllite/quartzite successions) are therefore expected to show more complex deformation in the cover strata.

\section{Conclusions}

The Supanberget area is one of the few areas in Wedel Jarlsberg Land where the structural style of the basement-involved zone of the Tertiary fold-and-thrust belt and the transition to the foreland structures can be continuously observed, although the ice cover is extensive. Our structural analysis shows that, as elsewhere on Spitsbergen, structures are of compressive origin, and are similar to those of other marginal fold-and-thrust belts.

The Supanberget thrust system is a basementinvolved, laterally discontinuous, imbricate system cutting folded, mostly overturned strata. It turns most likely into a detachment zone with a ramp-flat geometry in the overlying cover strata to the northeast. The minimum shortening associated with this structure exceeds $1 \mathrm{~km}$, but may be considerably greater. Foreland structures indicate at least one further detachment at a greater depth, through which deformation is translated north- 
eastward down below the western flank of the Tertiary central basin.

Basement composition and anisotropies clearly influence the structural style as the thrusts emerge from the basement into the cover. A well-developed anisotropy is thought to give rise to a more complex thrust system within the adjacent cover strata. In that way, basement anisotropies may locally control lateral structural changes in the fold-and-thrust belt.

\section{References}

Andresen, A., Bergh. S. Hansen, H., Kløvjan, O., Kristensen, S. E. Livbjerg. F. Lund. T. Mair, B. F., Midbøe. P. \& Nøttvedt. A. 1988a: Geometry and structural development of the Billefjorden and Lomfjorden fault zones in the IsfjordenSabine Land area. Spitsbergen. Abstr. 18. Nordiske Geologiske Vintermode. Copenhagen, Jan. 1988, 33-34.

Andresen, A., Haremo, P. \& Bergh, S. G. 1988b: The southern termination of the Lomfjorden Fault Zone; evidence for Tertiary compression on east Spitsbergen. Extended abstract, Symposium on Tertiary tectonics of Svalbard, Oslo 1988 Norsk Polarinstitutt Rapport 46, 75-78.

Bergh. S. G., Andresen, A., Bergvik, A. \& Hansen, A. I. 1988: Tertiary thin-skinned compressional deformation on Oscar II Land, central-west Spitsbergen. Extended abstract. Symposium on Tertiary tectonics of Svalbard, Oslo 1988. Norsk Polarinstitutt Rapport 46, 51-54.

Birkenmajer, K. 1964: Devonian, Carboniferous and Permian formations of Hornsund, Vestspitsbergen. Studia Geologica Polonica 11. 47-123.

Birkenmajer. K. 1972: Tertiary history of Spitsbergen and continental drift. Acta Geologica Polonica 22 (2), 193-218.

Birkenmajer, K. 1978: Cambrian succession in southern Spitsbergen. Studia Geologica Polonica 59,8-46.

Bjornerud, M. 1987: Structural evolution of a Proterozoic metasedimentary terrane, Wedel Jarlsberg Land. SW Spitsbergen. Ph.D. thesis, University of Wisconsin-Madison. $197 \mathrm{pp}$.

Boyer, S. E. \& Elliott. D. 1982: Thrust systems. American Association of Petroleum Geologists Bulletin 66 (9), 1196 1230.

Cutbill. J. L. \& Challinor, A. 1965: Revision of the stratigraphical scheme for the Carboniferous and Permian rocks of Spitsbergen and Bjørnøya. Geological Magazine 102.418439.

Dallmann. W. K. 1988a: The structure of the Berzeliustinden area: Evidence for thrust wedge tectonics in the Tertiary foldand-thrust belt of Spitsbergen. Polar Research 6. 141-154.

Dallmann, W. K. 1988b: Thrust tectonics south of Van Keulenfjorden. Extended abstract, Symposium on Tertiary tectonics of Svalbard. Oslo 1988. Norsk Polarinstitutt Rapport. 46, 43-45.

Dallmann, W. K. \& Maher, H. D., Jr. 1988: Thick- and thinskinned tectonics in the SW part of the Tertiary fold-andthrust belt. Spitsbergen. VI. Annual TSGS-meeting, Oslo, November 17-18th. Extended abstract. Institutt for geologi. Universitetet i Oslo, Intern skrifiserie 54, 10-11.

Eldholm, O. Faleide, J. I. \& Myhre, A. 1987: Continent-ocean transition at the western Barents Sea/Svalbard continental matgin. Geology 15, 1118-1122.
Flood, B., Nagy, J. \& Winsnes, T. S. 1971: Geological map Svalbard 1:500,000. Sheet 1G, Spitsbergen, southern part. Norsk Polarinstitutt Skrifter 154A.

Gretener, P. E. 1972: Thoughts on overthrust faulting in a layered sequence. Bulletin of Canadian Petroleum Geology $20,583-607$.

Handley, B. 1983: The structure and stratigraphy of the Hecla Hoek sequence (Precambrian) of western Midterhuken peninsula, Spitsbergen. M.S. thesis, University of WisconsinMadison. 97 pp.

Haremo, P. \& Andresen, A. 1988: Tertiary movements along the Billefjorden Fault Zone and its relation to the VestSpitsbergen orogenic belt. Extended abstract, Symposium on Tertiary tectonics of Svalbard, Oslo 1988. Norsk Polarinstitutt Rapport 46. 71-74.

Haremo, P., Andresen, A., Strand, K., Dypvik, H., Nagy, J., Elverhøi, A., Eikeland, T. A. \& Johansen, H. 1988: Strukturell utvikling av de mesozoiske og tertiare bergartene $\mathfrak{i}$ området Adventdalen/Sassendalen - Kjellstrømdalen, sentrale Spitsbergen, Svalbard. Abstr. 18, Nordiske Geologiske Vintermøde, Copenhagen, Jan. 1988, 155.

Harland. W. B. 1969: Contribution of Spitsbergen to understanding of the tectonic evolution of the North Atlantic region. American Association of Petroleum Geologists Bullein $12.817-851$.

Harland, W. B. 1978: A reconsideration of Late Precambrian stratigraphy of South Spitsbergen. Polarforschung 48, 61 .

Harland, W. B. \& Horsfield, W. T. 1974: The West Spitsbergen orogen. Pp. 747-755 in Spencer, A. M. (ed.): MesozoicCenozoic orogenic belts. Data for orogenic studies. Geological Society of London, Special Publication 4.

Hauser, E. C. 1982: Tectonic evolution of a segment of the West Spitsbergen fold belt in northern Wedel Jarlsberg Land. Ph.D. thesis, University of Wisconsin-Madison. $188 \mathrm{pp}$.

Kellogg, H. E. 1975: Tertiary stratigraphy and tectonism in Svalbard and continental drift. American Association of Petroleum Geologists Bulletin 59 (3), 465-485.

Lowell, J. D. 1972: Spitsbergen Tertiary orogenic belt and the Spitsbergen Fracture Zone. Geological Society of America Bulletin 83, 3091-3102.

Maher, H. D., Jr. 1988a: Photointerpretation of Tertiary structures in platform cover strata of interior Oscar II Land, Spitsbergen. Polar Research 6, 155-172.

Maher, H. D., Jr. 1988b: Minimum estimate of Tertiary shortening suggested by surface structures exposed on Midterhuken, Bellsund, Spitsbergen. Extended abstract, Symposium on Tertiary tectonics of Svalbard, Oslo 1988. Norsk Polarinstitutt Rapport 46, 35-38.

Maher, H. D., Jr. \& Craddock, C. C. 1988: Decoupling as an alternate model for transpression during the initial opening of the Norwegian-Greenland Sea. Polar Research 6, 137-140.

Maher, H. D. Jr., Craddock, C. C. \& Maher, K. M. 1986: Kinematics of Tertiary structures in Upper Paleozoic and Mesozoic strata on Midterhuken, west Spitsbergen. Geological Society of America Bulletin 97, 1411-1421.

Myhre, A. M., Eldholm, O. \& Sundvor, E. 1982: The margin between Senja and Spitsbergen fracture zones: Implications from plane tectonics. Tectonophysics 89, 33-50.

Mørk, A., Knarud, R. \& Worsley, D. 1982: Depositional and diagenetic environments of the Triassic and Lower Jurassic succession of Svalbard. Pp. 371-398 in Embry, A. F. \& Balkwill, H. R. (eds.): Arctic Geology and Geophysics. Canadian Society of Petroleum Geologists Memoir 8.

Nysæther, E. 1977: Investigations in the Carboniferous and 
Permian stratigraphy of the Torell Land area, Spitsbergen. Norsk Polarinstitutt Arbok 1976, 21-41.

Nøttvedt, A., Livbjerg, F., Midbøe, P. S., Eide, J. R., Kristensen, S. E., Rasmussen, E., Andresen, A. \& Bergh, S. 1988a: Upon the nature and history of Tertiary deformation in EastCentral Spitsbergen. Abstr. 18. Nordiske Geologiske Vintermøde, Copenhagen, Jan. 1988, 322-323.

Nøttvedt, A., Livbjerg, F. \& Midbøe, P. S. 1988b: Tertiary deformation of Svalbard - various models and recent advances. Extended abstract, Symposium on Tertiary tectonics of Svalbard, Oslo 1988. Norsk Polarinstitutt Rapport 46, 79-84.

Różycki, S. Z. 1959: Geology of the north-western part of Torell Land, Vestspitsbergen. Studia Geologica Polonica 2. $98 \mathrm{pp}$.

Spencer, A. M., Home, P. C. \& Berglund, L. T. 1984: Tertiary structural development of the western Barents Shelf: Troms to Svalbard. Pp. 199-209 in Spencer, A. M. (ed.): Petroleum geology of the north European margin. Graham \& Trotman, London.

Steel, R. J. \& Worsley, D. 1984: Svalbard's post-Caledonian strata - an atlas of sedimentary patterns and paleogeographic evolution. Pp. 109-135 in Spencer, A. M. (ed.): Petroleum geology of the north European margin. Graham \& Trotman, London.

Steel, R. J., Gjelberg, J., Helland-Hansen, W., Kleinspehn, K., Nøttvedt, A. \& Rye-Larsen, M. 1985: The Tertiary strike slip basins and orogenic belt of Spitsbergen. Society of Economic Paleontologists and Mineralogists Special Publication $37,339-360$.

Suppe, J. 1983: Geometry and kinematics of fault-bend folding. American Journal of Science 283, 684-721.

Vågnes, E., Reksnes, P. A., Faleide, J. I. \& Gudlaugsson, S. T. 1988: Plate-tectonic constraints on the formation of the Spitsbergen fold-and-thrust belt. Extended abstract, Symposium on Tertiary Tectonics of Svalbard, Oslo 1988. Norsk Polarinstitutt Rapport 46, 105-108.

Winsnes, T. S. \& Ohta, Y. 1988: Fold structures of Carboniferous to Triassic rocks in the upper part of St. Jonsfjorden. Extended abstract, Symposium on Tertiary Tectonics of Svalbard, Oslo 1988. Norsk Polarinstitutt Rapport 46, 21-24. 